\title{
Communication
}

\section{Decoration of $\mathrm{CuO}$ NWs Gas Sensor with $\mathrm{ZnO}$ NPs for Improving $\mathrm{NO}_{2}$ Sensing Characteristics}

\author{
Tae-Hee Han ${ }^{1}$, So-Young Bak ${ }^{2}$, Sangwoo Kim ${ }^{1}$, Se Hyeong Lee ${ }^{2}$, Ye-Ji Han ${ }^{1}$ and Moonsuk Yi ${ }^{2, *}$ \\ 1 Department of Smart Interdisciplinary Engineering, Pusan National University, Busan 46241, Korea; \\ hanthee00@pusan.ac.kr (T.-H.H.); $201210107 @$ pusan.ac.kr (S.K.); leopold00@pusan.ac.kr (Y.-J.H.) \\ 2 Department of Electronics Engineering, Pusan National University, Busan 46241, Korea; \\ bso6459027@pusan.ac.kr (S.-Y.B.); shlee12@pusan.ac.kr (S.H.L.) \\ * Correspondence: msyi@pusan.ac.kr; Tel.: +82-51-510-2381
}

check for updates

Citation: Han, T.-H.; Bak, S.-Y.; Kim,

S.; Lee, S.H.; Han, Y.-J.; Yi, M.

Decoration of CuO NWs Gas Sensor with $\mathrm{ZnO} N P$ s for Improving $\mathrm{NO}_{2}$ Sensing Characteristics. Sensors 2021, 21, 2103. https://doi.org/10.3390/ s21062103

Academic Editor: Eduard Llobet

Received: 9 February 2021

Accepted: 12 March 2021

Published: 17 March 2021

Publisher's Note: MDPI stays neutral with regard to jurisdictional claims in published maps and institutional affiliations.

Copyright: (C) 2021 by the authors Licensee MDPI, Basel, Switzerland. This article is an open access article distributed under the terms and conditions of the Creative Commons Attribution (CC BY) license (https:// creativecommons.org/licenses/by/ $4.0 /)$.

\begin{abstract}
This paper introduces a method for improving the sensitivity to $\mathrm{NO}_{2}$ gas of a p-type metal oxide semiconductor gas sensor. The gas sensor was fabricated using $\mathrm{CuO}$ nanowires (NWs) grown through thermal oxidation and decorated with $\mathrm{ZnO}$ nanoparticles (NPs) using a sol-gel method. The $\mathrm{CuO}$ gas sensor with a $\mathrm{ZnO}$ heterojunction exhibited better sensitivity to $\mathrm{NO}_{2}$ gas than the pristine $\mathrm{CuO}$ gas sensor. The heterojunction in $\mathrm{CuO} / \mathrm{ZnO}$ gas sensors caused a decrease in the width of the hole accumulation layer (HAL) and an increase in the initial resistance. The possibility to influence the width of the HAL helped improve the $\mathrm{NO}_{2}$ sensing characteristics of the gas sensor. The growth morphology, atomic composition, and crystal structure of the gas sensors were analyzed using field-emission scanning electron microscopy (FE-SEM), energy-dispersive X-ray spectroscopy, and X-ray diffraction, respectively.
\end{abstract}

Keywords: gas sensors; $\mathrm{CuO}$; nanowires; $\mathrm{ZnO} \mathrm{NPs}$; sol-gel; heterojunction

\section{Introduction}

Metal oxide semiconductor (MOS) gas sensors have been studied owing to their semipermanent performance, low price, easy manufacturing process, and high reactivity to gases [1-3]. MOS materials generally form adsorbed oxygen ions on nonstoichiometric surfaces at high temperatures $\left(200-400{ }^{\circ} \mathrm{C}\right)$ and also a superficial conductive layer or a depletion layer depending on the type of MOS material. In MOS gas sensors, a chemical reaction between the adsorbed oxygen ions and the target gas causes a change in the thickness of the surface layer, thereby changing the resistance [4]. MOS gas sensors can comprise n-type and p-type materials that generate an electrical core-shell by adsorbing oxygen $[5,6]$. When oxygen ions are adsorbed on the surface of a p-type oxide semiconductor at $200-400{ }^{\circ} \mathrm{C}$, a hole accumulation layer (HAL) and a high-resistance core are formed above and within the surface, respectively [7]. In general, when a p-type oxide semiconductor reacts to an oxidizing gas, the concentration of the surface holes increases and the resistance decreases [8]. Although the p-type MOS materials, such as $\mathrm{CuO}, \mathrm{Cr}_{2} \mathrm{O}_{3}$, and $\mathrm{NiO}$, show a high sensitivity to specific gases [7,9], they react less to oxidizing gases, compared to the n-type materials $[10,11]$. Therefore, there are less experimental results on p-type semiconductor materials than on n-type materials. However, the p-type materials are as important as n-type materials when used in gas sensors, such as complex gas sensor modules and electronic noses $[7,12,13]$.

$\mathrm{CuO}$ is a p-type MOS material with a narrow band of $1.2-1.8 \mathrm{eV}[14]$ and has excellent physical and electrical properties. $\mathrm{CuO}$ has been used in various applications, such as in solar cells [15], light emitting diodes (LEDs) [16], photocatalysts [17], and sensing materials $[18,19]$. However, $\mathrm{CuO}$ demonstrates a low sensitivity to oxidizing gases $[7,20]$. To improve its performance in gas reactions, various methods, such as doping and heterojunctions, have been studied [21,22]. 
In this work, we investigated the $\mathrm{CuO} / \mathrm{ZnO}$ heterojunction. $\mathrm{ZnO}$ is an n-type material that improves the sensitivity of gas sensors in the form of core-shell [23] and decoration particles [24]. In addition, a high-efficiency gas sensor was realized through thermal oxidation in a tube furnace. This process is not as complex as atomic layer deposition (ALD) [25] and hydrothermal synthesis [26].

In this study, a heterojunction was realized by decorating $\mathrm{CuO}$ nanowires (NWs) with $\mathrm{ZnO}$ nanoparticles (NPs) to improve the $\mathrm{NO}_{2}$ gas detection characteristics. The $\mathrm{CuO}$ NWs were grown through thermal oxidation [27], and the ZnO NPs were used to form a $\mathrm{CuO} / \mathrm{ZnO}$ heterojunction by employing a sol-gel method [28]. The sol-gel method is a simple yet highly efficient oxidization process that uses a sol-gel solution. The $p-n$ heterojunction of the $\mathrm{CuO}$ and $\mathrm{ZnO}$ interfaces successfully improved the sensitivity of the gas sensors to $\mathrm{NO}_{2}$ gas, as well as their response and recovery time, selective properties.

\section{Materials and Methods}

2.1. Growth of the $\mathrm{CuO} N W \mathrm{~S}$

The CuO NWs were grown through thermal oxidation of a $\mathrm{Cu}$ foil $(99.98 \%, 0.25 \mathrm{~mm}$ thickness, Sigma-Aldrich) in a tube furnace. The $\mathrm{Cu}$ foil had a surface of $2 \mathrm{~cm} \times 1 \mathrm{~cm}$ and, before undergoing thermal oxidation, it was cleaned in an aqueous solution of $1.5 \mathrm{M} \mathrm{HCl}$ for $1 \mathrm{~min}$. Subsequently, it was cleaned with an ultrasonicator in acetone and deionized (DI) water for $10 \mathrm{~min}$. The cleaned $\mathrm{Cu}$ foil was then placed on an alumina boat located in the middle of the tube furnace. The sample was heated to $600{ }^{\circ} \mathrm{C}\left(30^{\circ} \mathrm{C} / \mathrm{min}\right)$ for $3 \mathrm{~h}$ at atmospheric pressure. Once the thermal oxidation process was completed, the sample was cooled down in the tube furnace.

A CuO NW suspension was prepared by ultrasonic dispersion of the thermally oxidized $\mathrm{Cu}$ foil in a DI water $(2 \mathrm{~mL})$ and isopropyl alcohol $(1 \mathrm{~mL})$ solution. The $\mathrm{CuO}$ gas sensor was realized by dropping the $\mathrm{CuO}$ NW suspension onto an Au electrode, and then dried on a hotplate at $120^{\circ} \mathrm{C}$. After drying the solvent in the $\mathrm{CuO}$ NW slurry, the gas sensor was annealed at $400{ }^{\circ} \mathrm{C}$ for $1 \mathrm{~h}$ in the tube furnace.

\subsection{ZnO NPs Decoration on the CuO NWs Gas Sensor}

In this study, the concentrations of the $\mathrm{ZnO}$ sol-gel solutions in the $\mathrm{CuO} \mathrm{NW}$ sere $0.025,0.05$, and $0.075 \mathrm{M}$. Zinc acetate dihydrate $\left(\mathrm{Zn}\left(\mathrm{CH}_{3} \mathrm{COO}\right)_{2} \cdot 2 \mathrm{H}_{2} \mathrm{O}, 99.999 \%\right.$, SigmaAldrich) was dissolved in 2-methoxyethanol. The amount of stabilizer (Ethanolamine) added was four times the concentration of the solute. The sol-gel solution was stirred at $75^{\circ} \mathrm{C}$ and $500 \mathrm{rpm}$ for $1 \mathrm{~h}$ on a hot plate, and the impurities were removed using a $0.2 \mu \mathrm{m}$ syringe filter. The sol-gel solution was aged at $25^{\circ} \mathrm{C}$ for $24 \mathrm{~h}$ and then coated with a spin coater at $1000 \mathrm{rpm}$ for $30 \mathrm{~s}$ to form a CuO/ZnO heterojunction on the gas sensor. The $\mathrm{CuO}$ NWs coated with the $\mathrm{ZnO}$ sol-gel solution were dried for $10 \mathrm{~min}$ on a hot plate at $300{ }^{\circ} \mathrm{C}$ and then annealed for $1 \mathrm{~h}$ in the tube furnace at $500{ }^{\circ} \mathrm{C}$.

\section{Results and Discussion}

\subsection{Material Analysis}

3.1.1. Field-Emission Scanning Electron Microscopy (FE-SEM) and Energy-Dispersive $X$-ray Spectroscopy (EDS) Analyses

Figure 1 a shows the surface of a pristine $\mathrm{CuO}$ NW. The surface appears smooth, without any particles. The NWs had a length of 10-25 $\mu \mathrm{m}$ and a width of 300-600 nm. Figure $1 \mathrm{~b}$ shows the surface of the $0.025 \mathrm{M} \mathrm{ZnO} / \mathrm{CuO}$ NWs, in which small NPs were observed.

However, many NPs were observed on the surface of the $\mathrm{CuO}$ NWs decorated with $0.05 \mathrm{M} Z \mathrm{ZnO}$ NPs and 0.075 M ZnO NPs (Figure 1c,d respectively). These images show how many particles adhere to the surface of the NWs at different sol-gel concentration. Figure $1 \mathrm{~d}$ shows that an excessive concentration of sol-gel solution can destroy the structure of the nanowires.

Figure 2 presents the results of the EDS analysis on the pristine $\mathrm{CuO}$ and the 0.05 $\mathrm{M} \mathrm{CuO} / \mathrm{ZnO}$ gas sensors. The $\mathrm{Zn} \mathrm{K}$ peak was not detected in the pristine $\mathrm{CuO}$ sample, 
as depicted in Figure 2a. Figure $2 \mathrm{~b}$ shows that the $\mathrm{Zn} \mathrm{K}$ peak was detected at 3.78\% in the $0.05 \mathrm{M} \mathrm{CuO} / \mathrm{ZnO}$ gas sensor. As the concentration of the sol-gel solution increases, the weight of the detected $\mathrm{Zn} \mathrm{K}$ peak increases (Table 1).

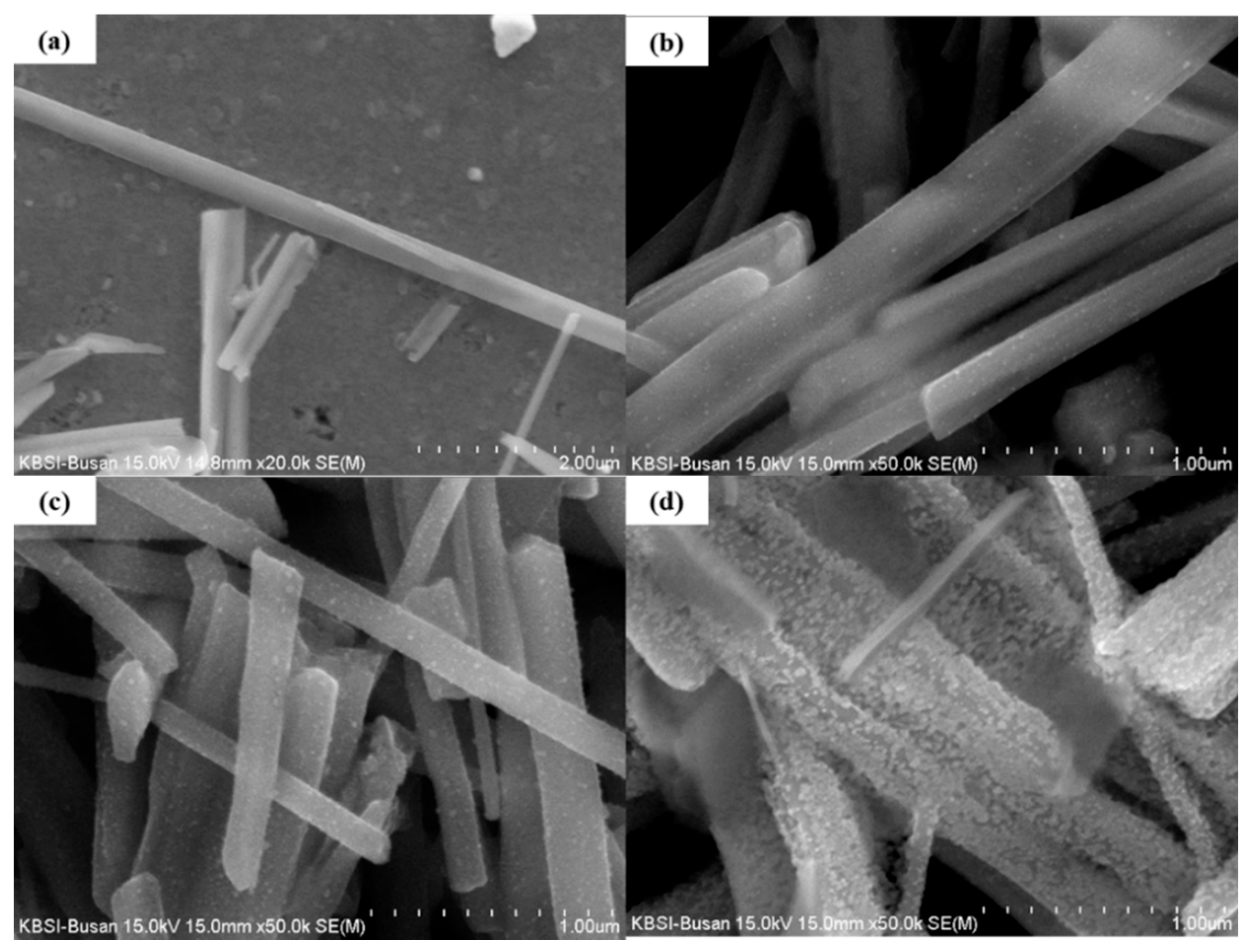

Figure 1. FE-SEM image of (a) pristine $\mathrm{CuO}$, (b) $\mathrm{CuO}$ NWs decorated with $0.025 \mathrm{M}$ ZnO NPs, (c) $\mathrm{CuO}$ NWs decorated with 0.05 M ZnO NPs, and (d) CuO NWs decorated with $0.075 \mathrm{M}$ ZnO NPs.

\section{(a) Pristine $\mathrm{CuO}$}
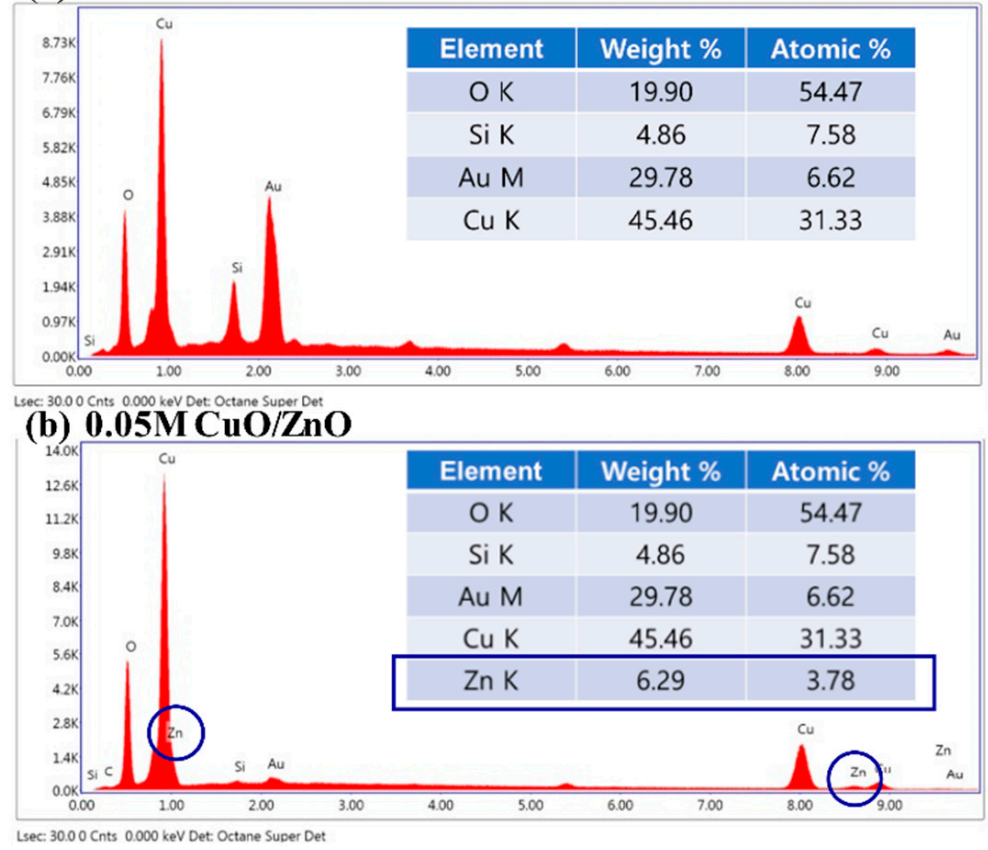

Figure 2. EDS analysis of (a) the pristine $\mathrm{CuO}$, and (b) the $0.05 \mathrm{M} \mathrm{CuO} / \mathrm{ZnO}$. 
Table 1. EDS analysis of the Zn K peak for different concentrations.

\begin{tabular}{ccccc}
\hline & $\begin{array}{c}\text { Pristine } \\
\mathrm{CuO}\end{array}$ & $\begin{array}{c}\mathbf{0 . 0 2 5} \mathbf{M} \\
\mathrm{CuO} / \mathrm{ZnO}\end{array}$ & $\begin{array}{c}\mathbf{0 . 0 5} \mathbf{M} \\
\mathrm{CuO} / \mathrm{ZnO}\end{array}$ & $\begin{array}{c}\mathbf{0 . 0 7 5} \mathbf{M} \\
\mathrm{CuO} / \mathrm{ZnO}\end{array}$ \\
\hline $\begin{array}{c}\text { Zn K Weight \% } \\
\text { (wt.\%) }\end{array}$ & - & 1.17 & 6.29 & 8.66 \\
$\begin{array}{c}\text { Zn K Atomic \% } \\
\text { (at\%) }\end{array}$ & - & 0.75 & 3.78 & 5.66 \\
\hline
\end{tabular}

The EDS mapping images are demonstrated in Figure 3. It was observed that the NWs primarily comprised $\mathrm{Cu}$ and $\mathrm{O}$. The Zn NPs were uniformly distributed over the entire area.

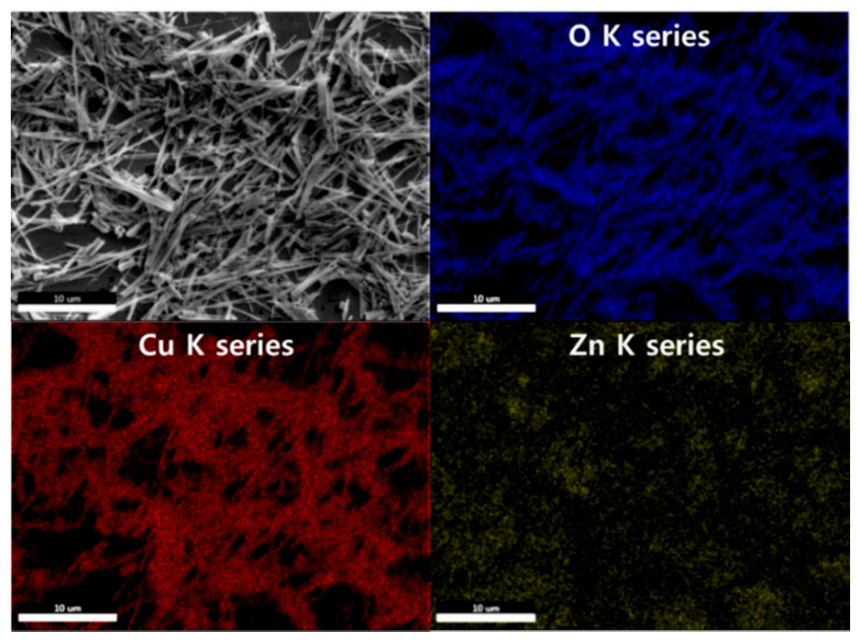

Figure 3. EDS mapping images of the $0.05 \mathrm{M} \mathrm{CuO} / \mathrm{ZnO}$ gas sensor.

\subsubsection{X-ray Diffraction (XRD) Analysis}

As shown in Figure 4, the crystal structures of the $0.05 \mathrm{M} \mathrm{CuO} / \mathrm{ZnO}$ gas sensor were analyzed using XRD. The XRD patterns were indexed to $\mathrm{CuO}$ (ICSD number 87125) and to the hexagonal structure of $\mathrm{ZnO}$ (ICSD number 162843). This confirmed that the crystalline $\mathrm{ZnO}$ NPs synthesized through the sol-gel method were formed on the $\mathrm{CuO}$ NWs. The $\mathrm{CuO}$ NWs exhibited a high peak in the (11) and (111) directions at $35.558^{\circ}$ and $38.748^{\circ}$, respectively. The $\mathrm{ZnO}$ nanoparticles exhibited a high peak in the (010), (002), and $(011)$ directions at $31.777^{\circ}, 34.426^{\circ}$, and $36.262^{\circ}$, respectively.

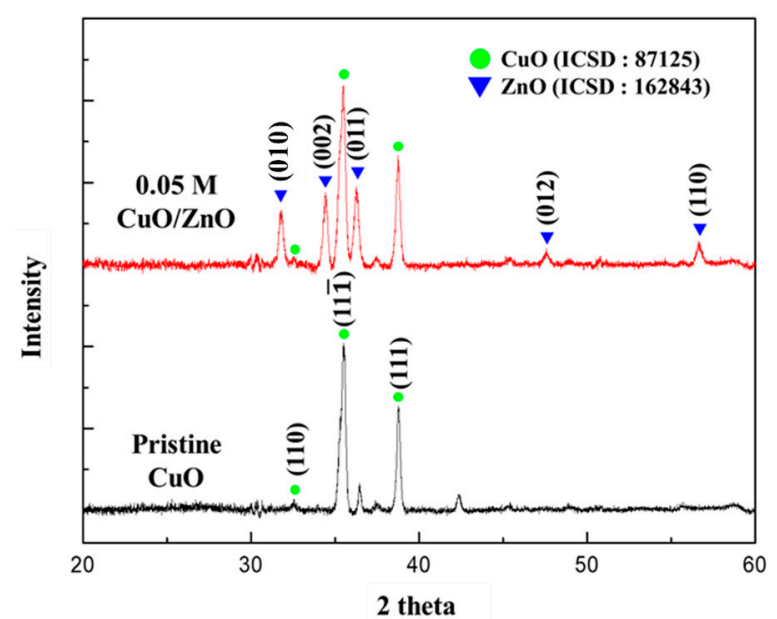

Figure 4. XRD analysis of the pristine $\mathrm{CuO}$ and the $0.05 \mathrm{M} \mathrm{CuO} / \mathrm{ZnO}$ gas sensor. 


\subsection{Effect of the $\mathrm{CuO} / \mathrm{ZnO}$ Heterojunction on Gas Sensing}

$\mathrm{CuO}$ and $\mathrm{ZnO}$ have band gaps of $1.8 \mathrm{eV}$ and $3.2 \mathrm{eV}$, respectively. As shown in Figure $5 \mathrm{a}$, when $\mathrm{p}-\mathrm{CuO}$ and $\mathrm{n}-\mathrm{ZnO}$ form a p-n heterojunction, the band curves towards the Fermi level, and a depletion layer is formed due to an electron and hole transfer process. Consequently, the HAL is partially suppressed, thereby increasing the resistance [29,30].

(a)

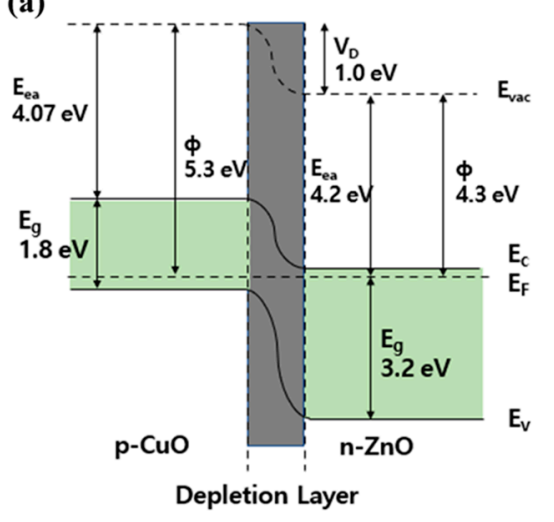

(b)

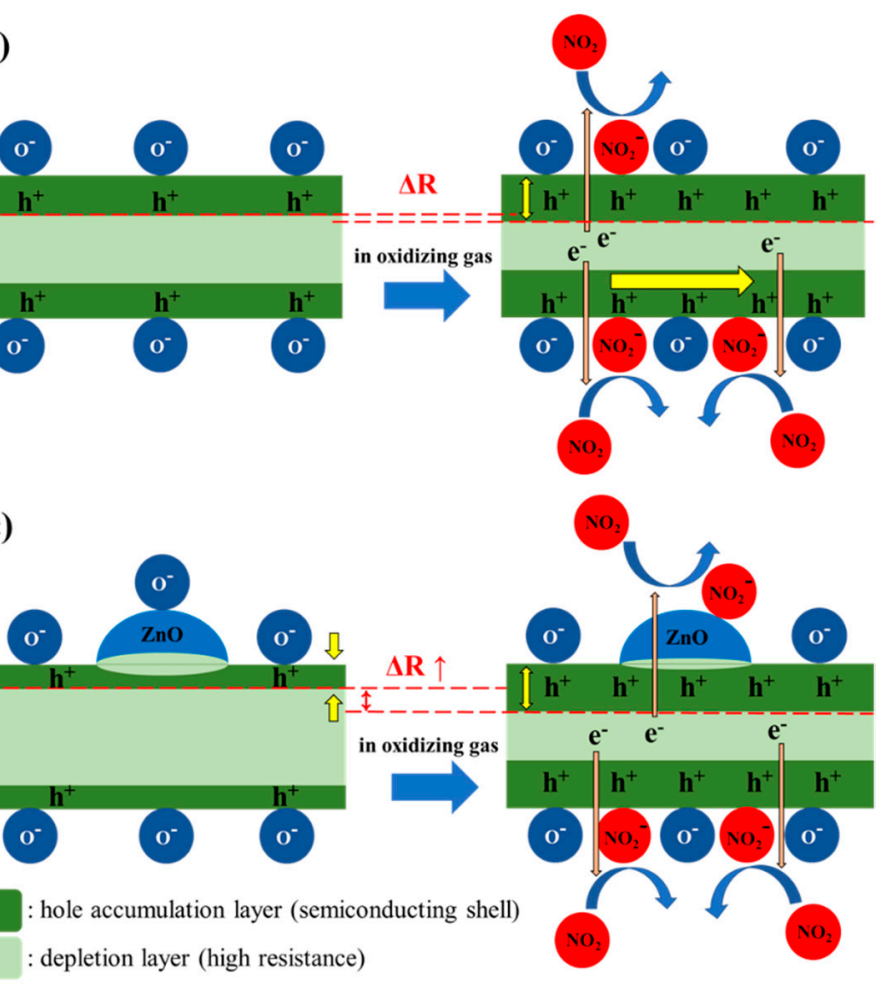

Figure 5. Schematic view of the effects caused by the $\mathrm{CuO} / \mathrm{ZnO}$ heterojunction. (a) Diagram of the $\mathrm{p}-\mathrm{CuO}$ and $\mathrm{n}-\mathrm{ZnO}$ heterojunction band; (b) Reaction of a $\mathrm{CuO} N W$ to $\mathrm{NO}_{2}$ gas; (c) Reaction of a CuO NW with $\mathrm{ZnO}$ heterojunction to $\mathrm{NO}_{2}$ gas.

As shown in Figure $5 b$, the pristine $\mathrm{CuO}$ NW formed a HAL below the surface and a depletion layer inside. This is because of the oxygen ions adsorbed on the surface that was exposed to air at $200-400{ }^{\circ} \mathrm{C}$. When the gas sensor was exposed to $\mathrm{NO}_{2}$, the oxidizing gas received electrons from the $\mathrm{CuONW}$ and was adsorbed in the form of $\mathrm{NO}_{2}{ }^{-}$ions on the surface. The corresponding loss of electrons in the $\mathrm{CuO} \mathrm{NW}$ increased the concentration of holes and decreased the resistance. The radial HAL width modulation of the $\mathrm{CuONW}$ heterojunction is shown in Figure 5c. The $\mathrm{CuO} / \mathrm{ZnO} N W$ has a higher resistance than the pristine $\mathrm{CuO}$ NW owing to a partial carrier suppression along the radial direction of the $\mathrm{ZnO}$ NPs. Therefore, the oxidizing gas improved the gas response as it causes a significant change in the width of the conductive HAL [31].

\subsection{Gas Sensing Performance}

The gas sensing characteristics were evaluated in a cleanroom where the temperature and relative humidity were maintained at $20-25{ }^{\circ} \mathrm{C}$ and at $40 \%-50 \%$, respectively. The gas measurement system consisted of 100 ppm cylinders of $\mathrm{NO}_{2}, \mathrm{NH}_{3}$, and $\mathrm{CO} ; \mathrm{N}_{2}(99.99 \%)$; a mass flow controller (MFC); and a pump (Figure 6). The gas sensor was located in the center of a $10 \mathrm{~cm} \times 10 \mathrm{~cm} \times 3 \mathrm{~cm}$ chamber. The MFC controlled the concentration of each gas by analyzing their flow rate. The pump discharged the gas to the outside and stabilized the pressure inside the chamber. The gas sensor, which was connected to electrodes that allowed current flow in the chamber, monitored the resistance. A change in the resistance indicated a reaction with the target gas. Before the reaction, the gas sensor was stabilized in an $\mathrm{N}_{2}$ atmosphere for $300 \mathrm{~s}$ and then exposed to $\mathrm{NO}_{2}$ gas for $300 \mathrm{~s}$. After the reaction, 
the gas sensor was stabilized in an only $\mathrm{N}_{2}$ atmosphere for $300 \mathrm{~s}$. The response of the $\mathrm{CuO}$ NW gas sensor to an oxidizing gas and a reducing gas was defined as $R_{a} / R_{g}$ and $R_{g} / R_{a}$, respectively, where $R_{a}$ is the resistance of the gas sensor before the reaction and $R_{g}$ is the resistance after the exposure to $\mathrm{NO}_{2}$ gas [32]. The sensitivity responses of $\mathrm{CuO}, 0.025 \mathrm{M}$ $\mathrm{CuO} / \mathrm{ZnO}, 0.05 \mathrm{M} \mathrm{CuO} / \mathrm{ZnO}$, and $0.075 \mathrm{M} \mathrm{CuO} / \mathrm{ZnO}$ to $100 \mathrm{ppm} \mathrm{NO}_{2}$ gas were measured at $250{ }^{\circ} \mathrm{C}$ (Figure 7).

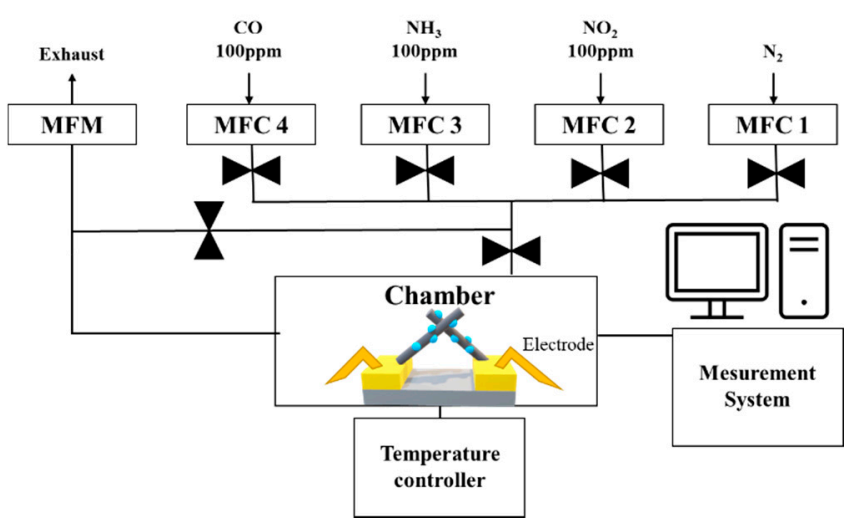

Figure 6. Architecture of the gas measurement system.

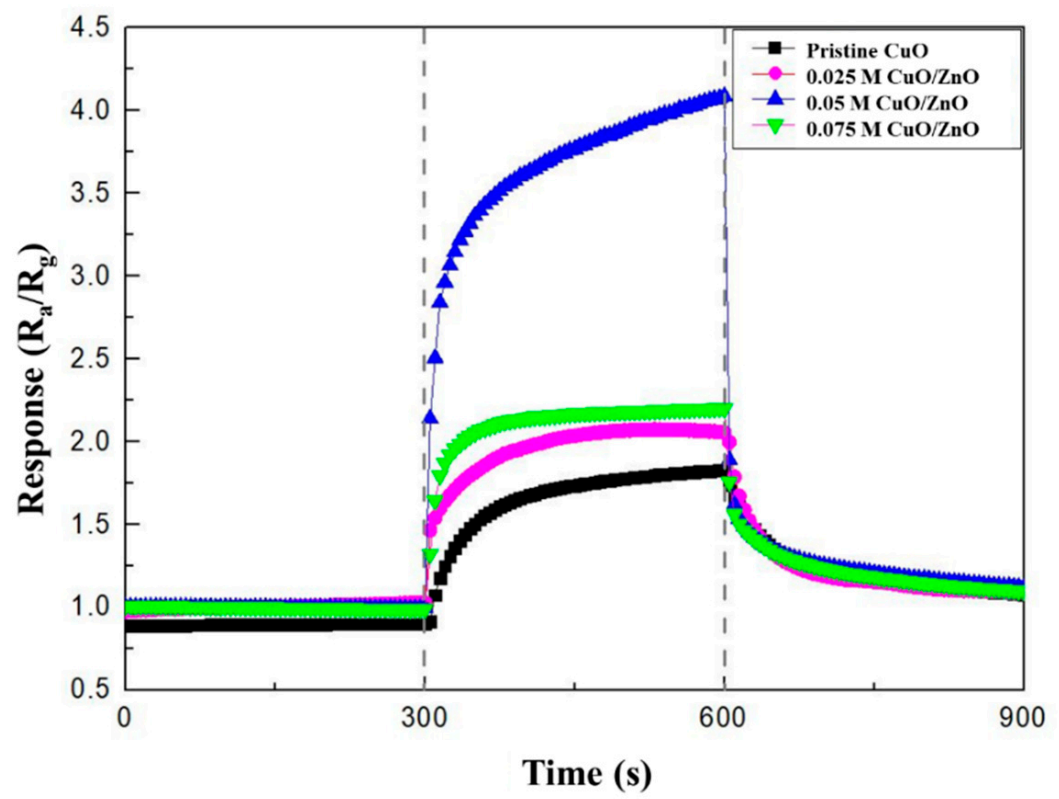

Figure 7. Response curves of the pristine $\mathrm{CuO}, 0.025 \mathrm{M} \mathrm{CuO} / \mathrm{ZnO}, 0.05 \mathrm{M} \mathrm{CuO} / \mathrm{ZnO}$, and $0.075 \mathrm{M}$ $\mathrm{CuO} / \mathrm{ZnO}$ to $100 \mathrm{ppm} \mathrm{NO}_{2}$.

The experimental results listed in Table 2 show that the $\mathrm{CuO} / \mathrm{ZnO}$ gas sensors have a better response, response time, and recovery time to $100 \mathrm{ppm} \mathrm{NO}_{2}$ gas at $250{ }^{\circ} \mathrm{C}$, than the pristine $\mathrm{CuO}$ gas sensor. In particular, with the $\mathrm{CuO} / \mathrm{ZnO}$ gas sensors, the response and recovery times were reduced from $60 \mathrm{~s}$ to $25 \mathrm{~s}$ and from $225 \mathrm{~s}$ to $150 \mathrm{~s}$, respectively. The best response to $\mathrm{NO}_{2}$ was observed in the $0.05 \mathrm{M} \mathrm{CuO} / \mathrm{ZnO}$ sensor. In fact, in this case the response was 4.1, which is 2.6 times higher than the response of the pristine $\mathrm{CuO}$ (1.58). The response to $\mathrm{NO}_{2}$ gas is worse in the $0.075 \mathrm{M} \mathrm{CuO} / \mathrm{ZnO}$. This is because, as shown in Figure $1 \mathrm{~d}$, an excessive concentration of $\mathrm{ZnO}$ covers most of the $\mathrm{CuO}$, thus causing a competitive reaction (with $\mathrm{CuO}$ ), affecting the sensitivity of the sensor. 
Table 2. Response, response time, and recovery time of CuO-based gas sensors (with different sol-gel concentration) to $100 \mathrm{ppm} \mathrm{NO}_{2}$ gas at $250{ }^{\circ} \mathrm{C}$.

\begin{tabular}{cccc}
\hline Sample & $\begin{array}{c}\text { Response } \\
\left(\mathbf{R}_{\mathbf{a}} / \mathbf{R}_{\mathbf{g}}\right)\end{array}$ & $\begin{array}{c}\text { Response } \\
\text { Time(s) }\end{array}$ & $\begin{array}{c}\text { Recovery } \\
\text { Time(s) }\end{array}$ \\
\hline $\begin{array}{c}\text { Pristine } \mathrm{CuO} \\
0.025 \mathrm{M}\end{array}$ & 1.58 & 60 & 225 \\
$\mathrm{CuO} / \mathrm{ZnO}$ & 2.0 & 65 & 180 \\
$0.05 \mathrm{M}$ & 4.1 & 25 & 150 \\
$\mathrm{CuO} / \mathrm{ZnO}$ & & 20 & 180 \\
$0.075 \mathrm{M}$ & 2.22 & 20 \\
$\mathrm{CuO} / \mathrm{ZnO}$ & & & \\
\hline
\end{tabular}

The response and recovery times were defined as the time required to reach $90 \%$ of the saturation and the time-limited response of the sensor, respectively [33]. The ZnO NPs improved the recovery and response times of the $\mathrm{CuO}$ gas sensors because they caused an increase in the surface of the gas sensor, and therefore in the surface reacting to the target gas [34]. Consequently, the adsorption and desorption of gas molecules on the surface of the gas sensor are accelerated (spillover effect) [35].

Figure 8 illustrates that as the $\mathrm{ZnO}$ sol-gel concentration increases, the resistance of the gas sensor $\left(R_{a}\right)$ increases owing to a reduction in the width of the HAL. This demonstrates that different heterojunctions were formed depending on the concentration of $\mathrm{ZnO}$.

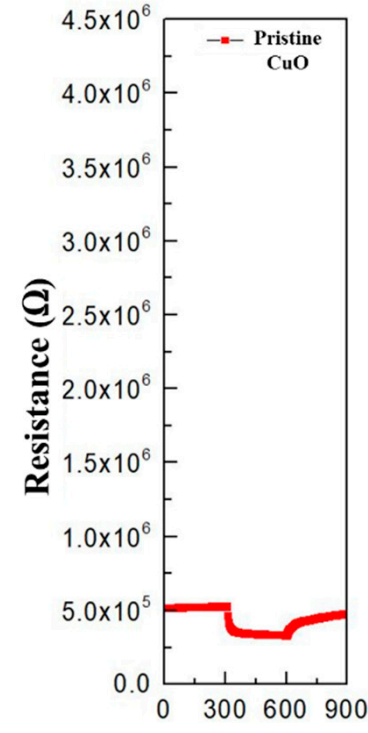

Time (s)

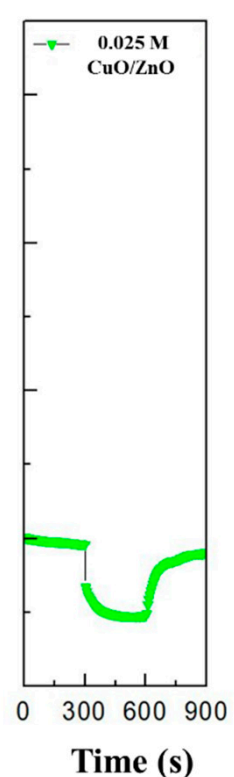

Time (s)
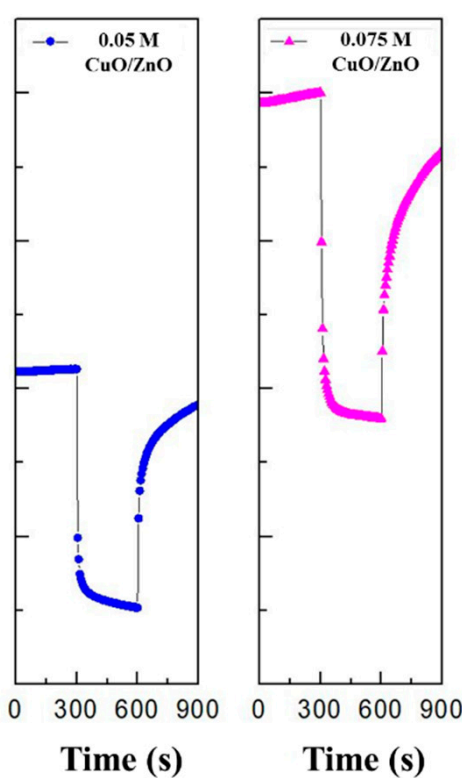

Figure 8. Resistance of the pristine $\mathrm{CuO}, 0.025 \mathrm{M} \mathrm{CuO} / \mathrm{ZnO}, 0.05 \mathrm{M} \mathrm{CuO} / \mathrm{ZnO}$, and $0.075 \mathrm{M}$ $\mathrm{CuO} / \mathrm{ZnO}$ to $100 \mathrm{ppm} \mathrm{NO}_{2}$.

To determine the optimal operating temperatures of the $\mathrm{CuO}$ and $0.05 \mathrm{M} \mathrm{CuO} / \mathrm{ZnO}$ gas sensors, their performance was evaluated using $100 \mathrm{ppm} \mathrm{NO}$ at various temperatures. Figure 9 a shows the resistance curves of the $\mathrm{CuO}$ and $0.05 \mathrm{M} \mathrm{CuO} / \mathrm{ZnO}$ at $200-300{ }^{\circ} \mathrm{C}$. The $\mathrm{CuO}$ decorated with $\mathrm{ZnO} N P s$ exhibited a significant change in the resistance; in fact, $\mathrm{CuO} / \mathrm{ZnO}$ gas sensors have a higher $\mathrm{R}_{\mathrm{a}}$ than the pristine $\mathrm{CuO}$ gas sensor. As the operating temperature increased, the resistance of both sensors decreased, which is a characteristic of a typical MOS device at high temperatures. As shown in Figure $9 \mathrm{~b}$, both the $\mathrm{CuO}$ and $0.05 \mathrm{M} \mathrm{CuO} / \mathrm{ZnO}$ sensors exhibited the best response at $250^{\circ} \mathrm{C}$. In general, the $\mathrm{CuO} / \mathrm{ZnO}$ heterojunction gas sensor exhibited a better response at all temperatures than the $\mathrm{CuO}$ gas sensor. 

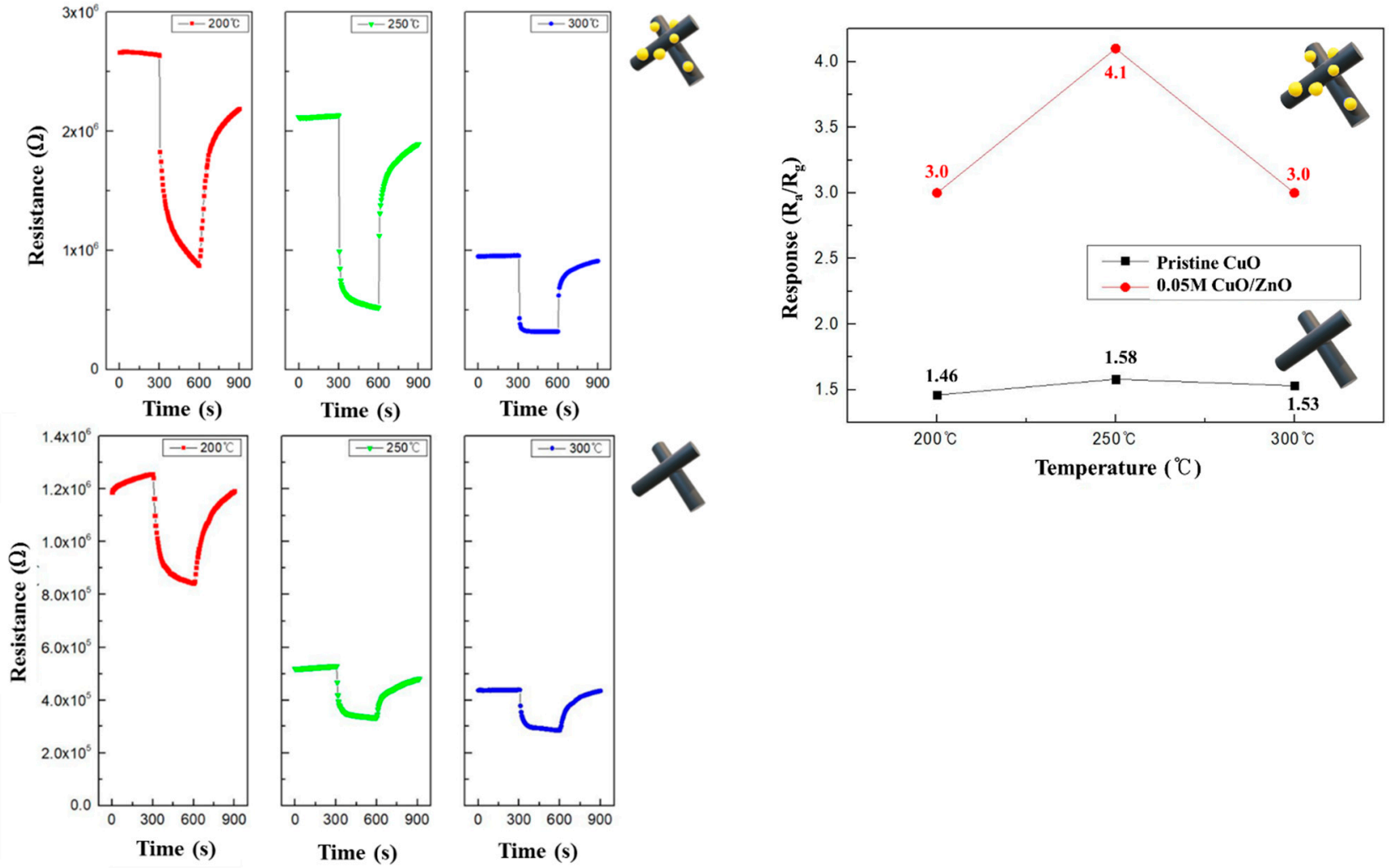

(b)

Figure 9. (a) Summary of the pristine $\mathrm{CuO}$ and $0.05 \mathrm{M} \mathrm{CuO} / \mathrm{ZnO}$ responses to $100 \mathrm{ppm} \mathrm{NO}_{2}$ at 200-300 ${ }^{\circ} \mathrm{C}$; (b) Response curves of the pristine $\mathrm{CuO}$ and $0.05 \mathrm{M} \mathrm{CuO} / \mathrm{ZnO}$ to $100 \mathrm{ppm} \mathrm{NO}_{2}$ at $200-300^{\circ} \mathrm{C}$.

Table 3 and Figure 10 summarize the response to $100 \mathrm{ppm} \mathrm{NO}, \mathrm{NH}_{3}$, and $\mathrm{CO}$ gases at $250{ }^{\circ} \mathrm{C}$. As mentioned before, the $\mathrm{CuO}$ NWs gas sensors are p-type semiconductor material. When they react to an oxidizing gas, such as $\mathrm{NO}_{2}$, their resistance decreases; thus, their sensitivity is expressed as $\mathrm{R}_{a} / \mathrm{R}_{\mathrm{g}}$. However, when $\mathrm{CuO}$ NWs gas sensors react with reducing gases, such as $\mathrm{NH}_{3}$ and $\mathrm{CO}$, their resistance increases; thus, their sensitivity is expressed as $\mathrm{R}_{\mathrm{g}} / \mathrm{R}_{\mathrm{a}}$. While the responses to $\mathrm{NH}_{3}$ and $\mathrm{CO}$ gases were similar, regardless of the type of heterojunction, a higher sensitivity to $\mathrm{NO}_{2}$ gas was observed in the same measurement conditions.

The response of the $0.05 \mathrm{M} \mathrm{CuO} / \mathrm{ZnO}$ gas sensor to $\mathrm{NO}_{2}$ gas was measured at different $\mathrm{NO}_{2}$ concentrations $(1-100 \mathrm{ppm})$ at $250{ }^{\circ} \mathrm{C}$. Figure 11 a shows that the response increased linearly (coefficient of determination, $\mathrm{R}^{2}=0.99$ ) as the $\mathrm{NO}_{2}$ gas concentration increased.

Table 4 briefly summarizes the response of the $\mathrm{CuO}$-based gas sensors obtained in previous works. The response of the $\mathrm{CuO}$ NWs without the heterojunction is similar to what we obtained [36-38]. Moreover, our study shows better results on the response of $\mathrm{CuO} / \mathrm{ZnO}$ heterojunction sensors to $\mathrm{NO}_{2}$ gas, compared to the results of [29] with the same $\mathrm{NO}_{2}$ concentrations.

Table 3. Response of the pristine $\mathrm{CuO}$ and $0.05 \mathrm{M} \mathrm{CuO} / \mathrm{ZnO}$ to $100 \mathrm{ppm} \mathrm{NO}, \mathrm{NH}_{3}$, and $\mathrm{CO}$ gas at $250{ }^{\circ} \mathrm{C}$.

\begin{tabular}{ccc}
\hline & $\begin{array}{c}\text { Pristine } \\
\text { CuO }\end{array}$ & $\begin{array}{c}\mathbf{0 . 0 5} \mathbf{M} \\
\mathrm{CuO} / \mathbf{Z n O}\end{array}$ \\
\hline $\mathrm{NO}_{2}$ & 1.58 & 4.1 \\
$\mathrm{NH}_{3}$ & 1.21 & 1.28 \\
$\mathrm{CO}$ & 1.19 & 1.18 \\
\hline
\end{tabular}




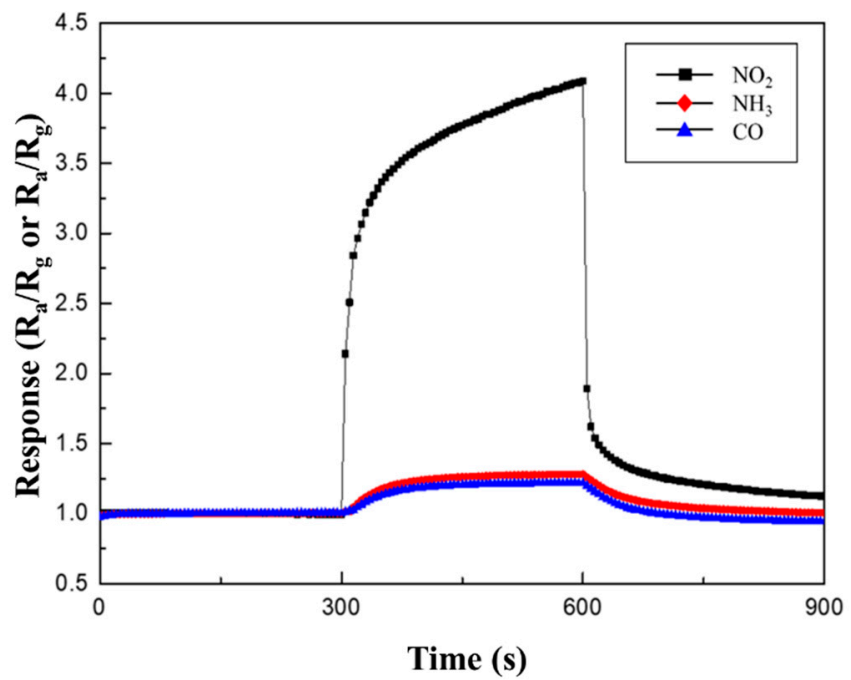

Figure 10. Response curves of $0.05 \mathrm{M} \mathrm{CuO} / \mathrm{ZnO}$ to $100 \mathrm{ppm} \mathrm{NO}, \mathrm{NH}_{3}$, and $\mathrm{CO}$ gases at $250{ }^{\circ} \mathrm{C}$.

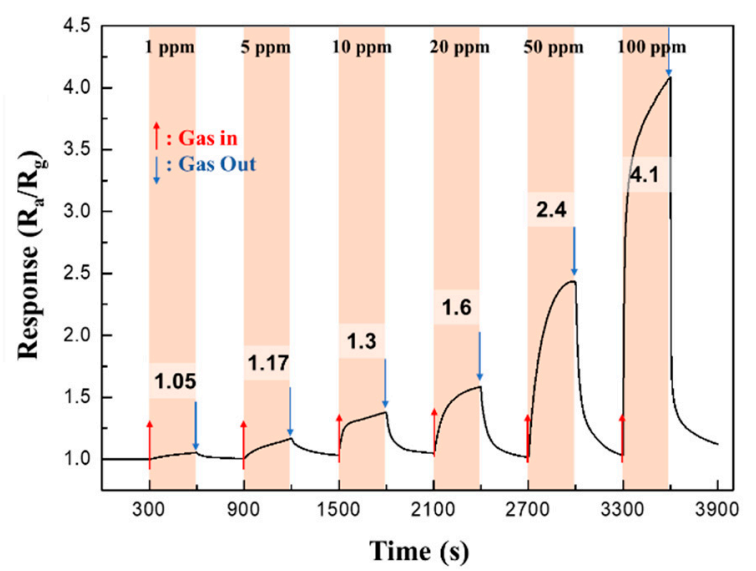

(a)

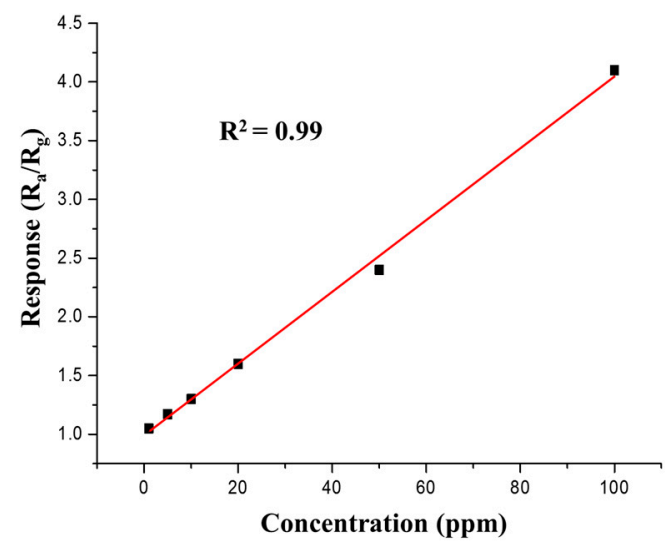

(b)

Figure 11. (a) Continuous response curves; (b) Response of the $0.05 \mathrm{M} \mathrm{CuO} / \mathrm{ZnO}$ gas sensor to $\mathrm{NO}_{2}$ at different concentrations of $\mathrm{NO}_{2}(1-100 \mathrm{ppm})$ at $250^{\circ} \mathrm{C}$.

Table 4. Brief summary of the response of CuO-based gas sensors.

\begin{tabular}{|c|c|c|c|c|c|c|}
\hline Material & Structure & Method & $\begin{array}{c}\text { Target Gas, } \\
\text { Concentration } \\
(\mathrm{ppm})\end{array}$ & $\begin{array}{c}\text { Operating } \\
\text { Temperature } \\
\left({ }^{\circ} \mathrm{C}\right)\end{array}$ & Gas Response & Ref. \\
\hline $\mathrm{CuO}$ & particles & $\begin{array}{c}\text { Thermal } \\
\text { decomposition }\end{array}$ & $\mathrm{NO}_{2}, 100$ & 200 & 1.5 & [36] \\
\hline $\mathrm{CuO}$ & nanowires & $\begin{array}{c}\text { Thermal } \\
\text { oxidation }\end{array}$ & $\mathrm{NO}_{2}, 4$ & 370 & 1.18 & [37] \\
\hline $\mathrm{CuO}$ & nanocubes & $\begin{array}{l}\text { Polyol } \\
\text { process }\end{array}$ & $\mathrm{NO}_{2}, 3$ & 300 & 0.4 & {$[38]$} \\
\hline $\mathrm{CuO@ZnO}$ & Core-shell & $\begin{array}{l}\text { Two-step } \\
\text { solution route }\end{array}$ & $\mathrm{C}_{2} \mathrm{H}_{5} \mathrm{OH}, 50$ & 240 & 3.6 & [39] \\
\hline $\mathrm{CuO}-\mathrm{ZnO}$ & Nanocomposites & $\begin{array}{l}\text { Chemical } \\
\text { method }\end{array}$ & $\mathrm{NO}_{2}, 100$ & 200 & $73 \%$ & [29] \\
\hline $\mathrm{CuO} / \mathrm{ZnO}$ & nanowires & $\begin{array}{l}\text { Thermal } \\
\text { oxidation }\end{array}$ & $\mathrm{NO}_{2}, 100$ & 250 & 4.1 & This work \\
\hline
\end{tabular}




\section{Conclusions}

We fabricated $\mathrm{CuO}$ NWs decorated with $\mathrm{ZnO}$ through thermal oxidation and a sol-gel method. The response, response time, and recovery time of the $\mathrm{CuO}$-based sensors to $\mathrm{NO}_{2}$ gas exposure were significantly improved using a p-n heterojunction to control the width of the HAL. The sensitivity of the pristine $\mathrm{CuO}$ gas sensor improved by a factor of 2.6 using a $0.05 \mathrm{M} \mathrm{ZnO}$ heterojunction. In addition, the response and recovery times were reduced from $60 \mathrm{~s}$ to $25 \mathrm{~s}$ and from $225 \mathrm{~s}$ to $150 \mathrm{~s}$, respectively. The $\mathrm{CuO} / \mathrm{ZnO}$ heterojunction gas sensor possessed a higher sensitivity to $\mathrm{NO}_{2}$, which is an oxidizing gas, than $\mathrm{NH}_{3}$ and $\mathrm{CO}$, which are reducing gases.

Author Contributions: Experiments and writing, T.-H.H., S.-Y.B., S.K., S.H.L. and Y.-J.H.; supervision, M.Y. All authors have read and agreed to the published version of the manuscript.

Funding: This research was supported by the Energy Cloud R\&D Program through the National Research Foundation of Korea (NRF) funded by the Ministry of Science, ICT (NRF-2019M3F2A1073385).

Institutional Review Board Statement: Not applicable.

Informed Consent Statement: Not applicable.

Data Availability Statement: Not applicable.

Conflicts of Interest: The authors declare no conflict of interest.

\section{References}

1. Yamazoe, N. Toward innovations of gas sensor technology. Sens. Actuators B Chem. 2005, 108, 2-14. [CrossRef]

2. Kaushik, A.; Kumar, R.; Jayant, R.D.; Nair, M. Nanostructures gas sensors for health care: An Overview. J. Pers. Nanomed. 2015, 1, 10-23. [PubMed]

3. Miller, D.R.; Akbar, S.A.; Morris, P.A. Nanoscale metal oxide-based heterojunctions for gas sensing: A review. Sens. Actuators B Chem. 2014, 204, 250-272. [CrossRef]

4. Dey, A. Semiconductor metal oxide gas sensors: A review. Sens. Actuators B Chem. 2018, 229, 206-217. [CrossRef]

5. Barsan, N.; Simon, C.; Heine, T.; Pokhrel, S.; Weimar, U. Modeling of sensing and transduction for p-type semiconducting metal oxide based gas sensors. J. Electroceram. 2010, 25, 11-19. [CrossRef]

6. Bejaoui, A.; Guerin, J.; Aguir, K. Modeling of a p-type resistive gas sensor in the presence of a reducing gas. Sens. Actuators B Chem. 2013, 181, 340-347. [CrossRef]

7. Kim, H.J.; Lee, J.H. Highly sensitive and selective gas sensors using p-type oxide semiconductors: Overview. Sens. Actuators $B$ Chem. 2014, 192, 607-627. [CrossRef]

8. Li, Y.; Wlodarski, W.; Galatsis, K.; Moslih, S.h.; Cole, J; Russo, S.; Rockelmann, N. Gas sensing properties of p-type semiconducting Cr-doped $\mathrm{TiO}_{2}$ thin films. Sens. Actuators $B$ Chem. 2002, 83, 160-163. [CrossRef]

9. Zhao, S.; Shen, Y.; Zhou, P.; Zhang, J.; Zhang, W.; Chen, X.; Wei, D.; Fang, P.; Shen, Y. Highly selective $\mathrm{NO}_{2}$ sensor based on p-type nanocrystalline $\mathrm{NiO}$ thin film prepared by sol-gel dip coating. Ceram. Int. 2018, 44, 753-759. [CrossRef]

10. Wisitsoraat, A.; Tuantranont, A.; Comini, E.; Sberveglieri, G.; Wlodarski, W. Characterization of n-type and p-type semiconductor gas sensors based on $\mathrm{NiO}_{x}$ doped $\mathrm{TiO}_{2}$ thin films. Thin Solid Films 2009, 517, 2775-2780. [CrossRef]

11. Li, D.; Hu, J.; Wu, R.; Lu, J.G. Conductometric chemical sensor based on individual CuO nanowires. Nanotechnology 2010, 21, 485502. [CrossRef] [PubMed]

12. Eranna, G.; Joshi, B.C.; Runthala, D.P.; Gupta, R.P. Oxide Materials for Development of Integrated Gas Sensors-A Comprehensive Review. Crit. Rev. Solid State Mater. Sci. 2004, 29, 111-188. [CrossRef]

13. Arshak, K.; Moore, E.; Lyons, G.M.; Harris, J.; Clifford, S. A review of gas sensors employed in electronic nose applications. Sens. Rev. 2004, 24 No.2, 181-198. [CrossRef]

14. Wu, D.; Zhang, Q. LSDA+U study of cupric oxide: Electronic structure and native point defects. Phys. Rev. B 2006, 73, 235206. [CrossRef]

15. Kidowaki, H.; Oku, T.; Akiyama, T.; Suzuki, A.; Jeyadevan, B.; Cuya, J. Fabrication and Characterization of CuO-based Solar Cells. J. Mater. Sci. Res. 2012, 1, 138-143. [CrossRef]

16. Barzegar, M.H.; Ghaedi, M.; Avargani, V.M.; Sabzehmeidani, M.M.; Sadeghfar, F.; Jannesar, R. Electrochemical synthesis and efficient photocatalytic degradation of azo dye alizarin yellow $\mathrm{R}$ by $\mathrm{Cu} / \mathrm{CuO}$ nanorods under visible LED light irradiation using experimental design methodology. Polyhedron 2019, 158, 506-514. [CrossRef]

17. Jin, Z.; Zhang, X.; Li, Y.; Li, S.; Lu, G. 5.1\% Apparent quantum efficiency for stable hydrogen generation over eosin-sensitized $\mathrm{CuO} / \mathrm{TiO}_{2}$ photocatalyst under visible light irradiation. Catal. Commun. 2007, 8, 1267-1273. [CrossRef]

18. Hoa, N.D.; Quy, N.V.; Tuan, M.A.; Hieu, N.V. Facile synthesis of p-type semiconducting cupric oxide nanowires and their gas-sensing properties. Phys. E 2009, 42, 146-149. [CrossRef] 
19. Lupan, O.; Postica, V.; Cretu, V.; Wolff, N.; Duppel, V.; Kienle, L.; Adelung, R. Single and networked CuO nanowires for highly sensitive p-type semiconductor gas sensor applications. Phys. Status Solidi RRL 2016, 10, 260-266. [CrossRef]

20. Hansen, B.J.; Kouklin, N.; Lu, G.; Lin, I.; Chen, J.; Zhang, X. Transport, Analyte Detection, and Opto-Electronic Response of p-Type CuO Nanowires. J. Phys. Chem. C 2010, 114, 2440-2447. [CrossRef]

21. Kim, K.M.; Jeong, H.M.; Kim, H.R.; Choi, K.I.; Kim, H.J.; Lee, J.H. Selective Detection of $\mathrm{NO}_{2}$ Using Cr-doped CuO Nanorods Sensors 2012, 12, 8013-8025. [CrossRef]

22. Na, C.W.; Woo, H.S.; Lee, J.H. Design of highly sensitive volatile organic compound sensors by controlling $\mathrm{NiO}$ loading on $\mathrm{ZnO}$ nanowire networks. RSC Adv. 2012, 2, 414-417. [CrossRef]

23. Choi, S.W.; Park, J.Y.; Kim, S.S. Synthesis of $\mathrm{SnO}_{2}-\mathrm{ZnO}$ core-shell nanofibers via a novel two-step process and their gas sensing properties. Nanotechnology 2009, 20,465603. [CrossRef] [PubMed]

24. Kaneti, Y.V.; Zakaria, Q.M.D.; Zhang, Z.; Chen, C.; Yue, J.; Liu, M.; Jiang, X.; Yu, A. Solvothermal synthesis of ZnO-decorated $\alpha-\mathrm{Fe}_{2} \mathrm{O}_{3}$ nanorods with highly enhanced gas-sensing performance toward n-butanol. J. Mater. Chem. A 2014, 2, 13283-13292. [CrossRef]

25. Boyadjiev, S.I.; Georgieva, V.; Yordanov, R.; Raicheva, Z.; Szilagyi, I.M. Preparation and characterization of ALD deposited ZnO thin films studied for gas sensors. Appl. Surf. Sci. 2016, 387, 1230-1235. [CrossRef]

26. Ruiz, A.M.; Sakai, G.; Cornet, A.; Shimanoe, K.; Morante, J.R.; Yamazoe, N. Microstructure control of thermally stable TiO 2 obtained by hydrothermal process for gas sensors. Sens. Actuators B Chem. 2004, 103, 312-317. [CrossRef]

27. Xu, C.H.; Woo, C.H.; Shi, S.Q. The effects of oxidative environments on the synthesis of CuO nanowires on Cu substrates. Superlattices Microstruct. 2004, 36, 31-38. [CrossRef]

28. Bak, S.-Y.; Lee, J.; Kim, Y.; Lee, S.-H.; Woo, K.; Lee, S.; Yi, M. Sensitivity Improvement of Urchin-Like ZnO Nanostructures Using Two-Dimensional Electron Gas in MgZnO/ZnO. Sensors 2019, 19, 5195. [CrossRef]

29. Mali, S.M.; Narwade, S.S.; Navale, Y.H.; Yayade, S.B.; Digraskar, R.V.; Patil, V.B.; Kumbhar, A.S.; Sathe, B.R. Heterostructural CuO-ZnO Nanocomposites: A Highly Selective Chemical and Electrochemical $\mathrm{NO}_{2}$ Sensor. ACS Omega 2019, 4, 20129-20141. [CrossRef]

30. Wang, L.; Kang, Y.; Wang, Y.; Zhu, B.; Zhang, S.; Huang, W.; Wang, S. CuO nanoparticle decorated ZnO nanorod sensor for low-temperature $\mathrm{H}_{2} \mathrm{~S}$ detection. Mater. Sci. Eng. C 2012, 32, 2079-2085. [CrossRef]

31. Choi, S.W.; Katoch, A.; Kim, J.H.; Kim, S.S. A novel approach to improving oxidizing-gas sensing ability of p-CuO nanowires using biased radial modulation of a hole-accumulation layer. J. Mater. Chem. C 2014, 2, 8911-8917. [CrossRef]

32. Matsunaga, N.; Sakai, G.; Shimanoe, K.; Yamazoe, N. Diffusion equation-based study of thin film semiconductor gas sensorresponse transient. Sens. Actuators B Chem. 2002, 83, 216-221. [CrossRef]

33. Mishra, V.N.; Agarwal, R.P. Sensitivity, response and recovery time of $\mathrm{SnO}_{2}$ based thick-film sensor array for $\mathrm{H}_{2}, \mathrm{CO}, \mathrm{CH}_{4}$ and LPG. Microelectron. J. 1998, 29, 861-874. [CrossRef]

34. Lee, J.H. Gas sensors using hierarchical and hollow oxide nanostructures: Overview. Sens. Actuators B Chem. 2009, 140, 319-336. [CrossRef]

35. Kwon, Y.J.; Mirzaei, A.; Kang, S.Y.; Choi, M.S.; Bang, J.H.; Kim, S.S.; Kim, H.W. Synthesis, characterization and gas sensing properties of ZnO-decorated MWCNTs. Appl. Surf. Sci. 2017, 413, 242-252. [CrossRef]

36. Li, Y.; Liang, J.; Tao, Z.; Chen, J. CuO particles and plates: Synthesis and gas-sensor application. Mater. Res. Bull. 2008, 43, 2380-2385. [CrossRef]

37. Kim, Y.S.; Hwang, I.S.; Kim, S.J.; Lee, C.Y.; Lee, J.H. CuO nanowire gas sensors for air quality control in automotive cabin. Sens. Actuators B Chem. 2008, 135, 298-303. [CrossRef]

38. Park, H.J.; Choi, N.J.; Kang, H.; Jung, M.Y.; Park, J.W.; Park, K.H.; Lee, D.S. A ppb-level formaldehyde gas sensor based on CuO nanocubes prepared using a polyol process. Sens. Actuators B Chem. 2014, 203, 282-288. [CrossRef]

39. Yin, M.; Wang, F.; Fan, H.; Xu, L.; Liu, S. Heterojunction CuO@ZnO microcubes for superior p-type gas sensor application. J. Alloys Compd. 2016, 672, 374-379. [CrossRef] 